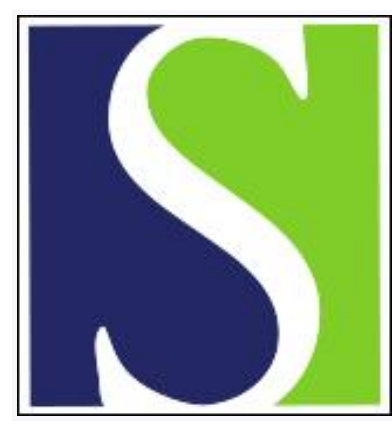

Scand J Work Environ Health 1994;20(1):65-66

https://doi.org/10.5271/sjweh.1426

Issue date: $01 \mathrm{Feb} 1994$

Nordic cooperation in research on the work environment.

by Orhede E

The following articles refer to this text: 2013;39(5):468-476;

2019;45(3):239-247; 2021;47(4):287-295

This article in PubMed: www.ncbi.nlm.nih.gov/pubmed/8016602

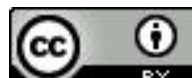




\section{Nordic cooperation in research on the work environment}

From 1985 to 1988 a questionnaire on work environments and health was compiled by a group of Nordic researchers. The purpose of providing a common Nordic questionnaire was to make comparative analyses of the work environment possible in the Nordic countries.

The researchers have proposed that the questionnaire be used for screening the work environment and health conditions for larger numbers of employees. It is intended to be used in enquete studies.

The questionnaire includes 104 questions on the following issues: (i) general background information, (ii) work conditions and the organization of work, (iii) physical and chemical exposures at work, (iv) psychosocial factors, and (v) health symptoms.

In 1987 the questionnaire was evaluated through pilot studies in Sweden and Denmark before the final version was introduced. Surveys on representative samples of 1000 employees in each country were carried out. Different aspects of the questionnaire were to be evaluated in the two countries. The Danish study focused on the length of the questionnaire and a special classification of work processes. In the Swedish study different formulations of several questions were evaluated. In the studies a reference period of 3 and 12 months, respectively, was tested for the questions on symptoms. The samples were divided into two subsamples, each with 500 employees in both countries. One-half received a questionnaire with a reference period of three months, the other half received a questionnaire with a reference period of 12 months for the questions on symptoms. The results from the pilot studies caused some alterations in the formulations of the questions, but the questionnaire kept its original size, and the length was considered proper. The most significant result was that no difference in the frequency of reported symptoms was found whether the reference period was 3 or 12 months $(1,2)$. The work group therefore agreed to recommend the use of a three-month reference period in future screening studies of the work environment and health to reduce errors originating from memory deficiency.

In 1989 and 1990 cross-sectional studies on the work environment and health conditions were carried out in Sweden, Norway, Finland, and Denmark using the Nordic questionnaire as the basic questionnaire in all four studies. The sample size varied from 10000 in Sweden to 4500 in Norway. Altogether 25000 employees in the four countries participated in the surveys. The main results have been published in the original languages in each country $(3-10)$.
Data from the surveys have been compiled into a Nordic data base comprising 85 variables comparable among the countries. The data base is situated in the Danish Data Archives. The data base has been prepared in an English language version and is also accessible in a version including the original languages, except for Finnish. The Finnish questions have been translated into Swedish. Access to the data base can be obtained by application to the Danish Data Archives, which handles the formalities related to permission.

The questionnaire was further used in a survey on the work environment and health carried out in all countries in the European Community in 1991 (11, 12). Part of it has been translated into French and is currently being used in a survey being performed on the organization of work by the French Ministry of Labour. Finally, at least some of the questions have been used in Denmark in new research on the work environment and health, in the cleaning industry (13) and in a study on cardiovascular disease among Danish workers (14).

The following researchers participated in developing the common Nordic questionnaire:

Bjørn Hilt, Clinic of Occupational Health, Porsgrunn, Norway

Gunnar Mowé, Institute of Occupational Hygiene, Oslo, Norway

Monica Hane, Occupational Health Clinic, Örebro, Sweden

Mats Hagberg, National Institute of Occupational Health, Solna, Sweden

Anders Wikman, Statistics Sweden, Stockholm, Sweden

Timo Partanen, Finnish Institute of Occupational Health, Helsinki, Finland

Timo Kauppinen, Finnish Institute of Occupational Health, Helsinki, Finland

Anna-Maija Lehto, Central Statistical Office, Helsinki, Finland

Mogens Nord-Larsen, National Institute of Social Research, Copenhagen, Denmark

Niels Kristian Rasmussen, Institute of Clinical Epidemiology, Copenhagen, Denmark

Elsa Bach, National Institute of Occupational Health, Copenhagen, Denmark

Elsa Ørhede, Coordinator of the project, National Institute of Occupational Health, Copenhagen, Denmark 
The questionnaire is obtainable, by request, from:

Elsa Ørhede

Danish National Institute of Occupational Health

Department of Occupational Medicine

Lersø Park Alle 105

DK-2100 Copenhagen $\emptyset$

Denmark

The following address can be used to contact the Danish Data Archives:

Danish Data Archives

Islandsgade 10

DK-5000 Odense C

Denmark

\section{References}

1. Ørhede E, Wikman A. Pilotprojekterne i Danmark og Sverige, 1987. Arbejdsmiljøinstituttet, 1987.

2. Wikman A. Att utveckla sociala indikatorer. En surveyansats belyst med exemplet arbetsmiljö [dissertation]. Stockholm: Statistiska centralbyrån, 1991. (Urval, nummer 21.)

3. Wikman A. Kvinnors och mäns arbetsmiljö. Stockholm: Statistiska centralbyrån, 1991. (Information om arbetsmarknaden 1991:1).

4. Prieto HP. Datorer och arbetsmiliö. Stockholm: Stockholm: Statistiska centralbyrån, 1991. (Information om arbetsmarknaden 1991:3).

5. Ljunggren G. Den psykosociala arbetsmiljön. Stockholm: Statistiska centralbyrån, 1992. (Information om arbetsmarknaden 1992:4).
6. Faye A. Arbeidsmiljø 1989. Statistisk Sentralbyrå, Oslo-Kongsvinger, 1992.

7. Lehto A-M. Työelämän laau ja tasa-arvo: komiteanmietintö 1991:39. Helsinki: Tilastokeskus, 1992. (Tutkimuksia 189).

8. Kolu T. Työelämän laatu 1977-1990: Komiteanmietintö 1991:38. Helsinki: Tilastokeskus, 1992. (Tutkimuksia 188.)

9. Nord-Larsen M, Ørhede E, Nielsen J, Burr H. Lønmodtagernes arbejsmiljø 1990-bind 1, Sammenhange mellem arbejdsmiljø og helbred. Arbedsmiljøfondet, 1992.

10. Ørhede E, Nord-Larsen M, Burr H, Nielsen J. Lønmodtagernes arbejsmiljø 1990-bind 2. Kortlægning af påvirkninger, arbejdsprocesser og helbred. Arbejsmiljøfondet, 1992.

11. Paoli P. First European survey on the work environment 1991. Dublin: European Foundation for the Improvement of Living and Working Conditions, 1992.

12. Ørhede E. The work environment in EC 1991. Copenhagen: National Institute of Occupational Health, 1993.

13. Nielsen J. Arbejsmiljø og helbredsforhold blandt rengøringskvinder. Stockholm: Arbejsmiljøfondet, 1993.

14. Netterstrøm B, Nielsen F, Ørhede E. Jobkarakteristika hos myokardieinfarkt patienter. Stockholm: Arbejsmiljøfondet, 1993.

Elsa Ørhede, MSc

National Institute of Occupational Health

Lersø Park Alle 105

DK-2100 Copenhagen $\emptyset$

Denmark 